\title{
Mechanisms of Selected Plant Hormones under Heavy Metal Stress
}

\author{
Abolghassem Emamverdian ${ }^{1,2}$, Yulong Ding ${ }^{1,2 *}$, \\ Farzad Mokhberdoran ${ }^{3}$, Zishan Ahmad ${ }^{1,2}$ \\ ${ }^{1}$ Co-Innovation Center for Sustainable Forestry in Southern China, Nanjing Forestry University, Nanjing, 210037, China \\ ${ }^{2}$ Bamboo Research Institute, Nanjing Forestry University, Nanjing, 210037, China \\ ${ }^{3}$ Department of Agronomy and Plant Breeding, Faculty of Agriculture, Islamic Azad University, \\ Mashhad Branch, Mashhad 9187147578, Iran
}

Received: 4 April 2020

Accepted: 25 May 2020

\begin{abstract}
The present review focuses on the role of auxin (IAA), cytokinins (CKs), ethylene (ET) and abscisic acid (ABA) under heavy metal stress. From the onset of heavy metal stress in plants, cellular levels of ABA tend to increase, leading to the establishment of signal communication and encoding of genes associated with the enzymes involved in antioxidant stress responses. The mechanisms of IAA phytohormones in terms of enhancing plant tolerance to stress mainly comprise developing a link between hydrogen peroxide $\left(\mathrm{H}_{2} \mathrm{O}_{2}\right)$ and auxin homeostasis, which can result in forming a signaling interaction between them. The primary anti-phytotoxicity mechanism of ET in response to heavy metal stress is related to modulating the interaction of ethylene with reactive oxygen species (ROS) signaling, which is reflected in a synergy between induction of ROS and synthesis of 1-aminocyclopropane-1-carboxylic acid (ACC). CKs, particularly when applied exogenously, make a positive contribution to alleviating stress emanating from plant metal exposure. This is achieved by a reduction in ROS levels inside plant cells. Generally, CKs can ameliorate heavy metal stresses via a three-way interaction involving exogenous CK, CK metabolism, and CK signaling. Our aims in this work were to review the major hormonal responses of plants elicited by heavy metal stress.
\end{abstract}

Keywords: abiotic stresses, abscisic acid, auxin, cytokinins, and ethylene

\section{Introduction}

Phytohormones are present in plant tissues either at low or high concentrations but are actively involved as chemical messengers in cellular processes [1]. Plants

*e-mail: ylding@vip.163.com encounter many abiotic and biotic environmental stresses during their lifetime. It is important to know how a plant can perceive and transfer these stress signals into its physiological reaction sites to ameliorate abiotic stress such as excess of heavy metals [2]. Additionally, plant hormones act as signaling regulators mediating a link between plant and environmental cues. Hormones as a link of communication can influence internal metabolic processes of the plant via external 
signals. This regulates plant growth and development, especially under stressful conditions [3]. Among phyto-hormones, abscisic acid (ABA) is one of the important hormones that can impact the efficiency and functionality of other hormones [3]. ABA controls and regulates gene expression connected with the signaling molecules involved in stress responses, leading to amelioration of environmental stresses faced by plants, and as a result, it is called a "stress hormone" [4]. ABA acts as a sensor (ABA-Sensor) for perception of external stress factors by plants [5]. Auxins (IAA) is another important phyto-hormone [6-7], which plays an essential role in an array of plant's basic processes of life including embryogenesis, vascular tissue formation, organ differentiation and is involved in regulating plant defense responses to environmental stress [8]. Cytokinin (CK) participates in cellular function of higher plants in various forms including zeatin, dihydrozeatin and isopentenyladenine [9-10]. There is an inverse relationship between the reduced $\mathrm{CK}$ concentration in plant and the accumulation of ABA that can lead to improving plant resistance to stress [11]. Ethylene (ET) as one of the essential phytohormones plays a vital role in plant growth regulation. ET at the appropriate level $\left(10 \mathrm{~g} \mathrm{~L}^{-1}\right)$ can modulate seed dormancy and seed germination process [12]. 1-aminocyclopropane-1carboxylic acid (ACC) has an essential role in ethylene biosynthesis [13]. With the excess of heavy metals in the plant and the onset of oxidative stress, ACC takes on an important role to ameliorate early oxidative stress by forming a link between ACC and glutathione (GSH) [14]. In a study on Arabidopsis thaliana, the results revealed that ACC was able to control oxidative stress caused by cadmium by impacting signaling genes and alteration in GSH concentration. This shows that ACC stimulates antioxidant defense mechanisms against heavy metals stress [15]. In general, the impact of excess metals on the induction of ethylene is metal type and concentration dependent. It is reported that $\mathrm{Cd}$, as a toxic nonessential element, has a significant role in stimulating ethylene, raising ethylene levels within plant tissues [16]. Today, with increasing anthropogenic activity, the problem of heavy metal contamination is one of the major concerns for humans. Therefore, it is necessary to introduce and identify determining factors in containing these stressors in plants. In this article, we reviewed the mechanism involved in reducing abiotic stress especially heavy metals by phytohormones in plants based on recent studies.

\section{Phytohormones and Defense Mechanisms}

By impacting accumulation and transfer of metal ions within plant organs and tissues, as well as by stimulating plant antioxidant enzymatic activity, ABA can mitigate heavy metal stress and protect plant cells [17-18]. The root meristems have been known as primary production sites for ABA. Consequently, ABA can provide initial protection barrier against heavy metal excess in the rhizosphere as plants first come into contact with metal ions in the soil. In a study on Phragmites and Typha, it was found that Cd-induced ABA accumulation in the plant roots was considerably more conspicuous than the shoots, conferring enhanced tolerance to the metal stress [19]. Therefore, it seems that the enhanced ABA concentration in root has a role in reducing the ion activities of metals. The link between auxin signaling and ROS metabolism is crucial to adjusting plant growth and development under stressful conditions [20]. $\mathrm{H}_{2} \mathrm{O}_{2}$ is an important component of ROS that not only affects plant vital processes such as photosynthesis and transpiration but also participates in signal transduction system. The molecular characteristics leading to the effectiveness of $\mathrm{H}_{2} \mathrm{O}_{2}$ in signaling processes include features such as limited reactivity and protracted life duration [21]. Cytokinins (CKs), applied exogenously to plant, can ameliorate heavy metal stress through pathways involving CK metabolism and CK signaling [22]. There is a reverse relationship between the change in levels of $\mathrm{ABA}$ and $\mathrm{CK}$ where $\mathrm{CK}$ and $\mathrm{ABA}$ act antagonistically to one another [23], which can result in plant enhanced resistance to stress through increasing apical dominance and regulating stomatal aperture [11]. Additionally, it is reported that $\mathrm{ABA}$ and ethylene participate in plant growth and development via both antagonistic and synergistic actions [24]. Ethylene is one of the important stress hormones under adverse environmental conditions [25-26-27]. Aminocyclopropane-1-carboxylic acid synthase (ACC synthase, ACS) is an enzyme that is involved in ethylene biosynthesis. ACC oxidase converts ACC (1-aminocyclopropane-1-carboxylic acid) to ethylene [12]. These processes occur when plants are exposed to different living and non-living stresses [12]. In heavy metal stress conditions, ACC synthase activity increases with rising ACC levels in plants [16-28]. In this condition, the amount of ACC improves plant defense against stress and preserves proteins involved in the activation and transcription of stress-related genes. These genes are responsible for encoding proteins that have protective role in plants in stress conditions [29]. In the following, we refer to the major mechanisms adopted by the four main phytohormone groups to counteract abiotic stresses, in particular, heavy metals.

\section{The role of IAA in Response to Abiotic Stress}

Auxin is known as a signaling molecule with important roles during plant life such as cell division and expansion, embryogenesis, meristem development, maintenance of polarity and tissue and organ development [30-31]. Also, auxin plays an essential role in plant growth and development processes including tropic responses, organ pattern formation, apical dominance and vascular development [31-32]. There are more than four auxin forms in plants, including 1-indole-3-acetic acid (IAA), 2-ndole-3-propionic acid 
(IPA), 3-indole-3-butyric acid (IBA), 4-4-chloroindole3-acetic acid (4-CI-IAA) and 3-phenylacetic acid (PAA). IAA is the most important auxin, and makes up approximately $1 \%$ of auxins in total plant tissue [33]. IAA is a phytohormone (indole-3-acetic acid. IAA) with an important mediatory role in plant growth and development [2]. Also, auxin is an integrator of environmental signals [30]. It is present in nearly all plant parts and organs so that it forms gradients of auxin in plants. This gradient of auxin is predisposed to change depending on plant variables such as plant organ, growth stage and stress type [34]. The pathway of indole-3-pyruvic acid (IpyA) biosynthesis and activities of its associated enzymes can lead to auxin generation in plants [35]. The production and transfer of auxin in plants are facilitated by different auxin transport proteins such as auxin influx protein AUXIN RESISTANT 1 (Aux 1), auxin influx protein AUX 1-LIKE (LAX) and auxin influx protein Pin [34]. The auxin transfer genes are encoded by ATP binding cassette B/P-glycoprotein (ABCB/PGP) families and PIN-FORMED (PIN) membrane proteins [36]. In a study with Arabidopsis, it was revealed that Aux 1 plays an important role as a mediator in (IAA) transportation [37-38-39]. In another study conducted on Cd-stressed rice (Oryza sativa L.), OsAUX1 was found to have a pivotal role in the plant response to cadmium, positively affecting the growth and development of the root under the stress condition [40].

\section{Metal Stress}

The signaling role of ROS can improve plant response and adaptation under stress [20]. It is reported that $\cdot \operatorname{ROS}$ compounds such as $\mathrm{H}_{2} \mathrm{O}_{2}, \mathrm{O}_{2}$ and $\mathrm{OH}$ can contribute to cell elongation via the mediation of auxin [20]. In maize, it is shown that ROS can be beneficial to the auxin-regulated gravitropism [41]. Zhao et al. 2012 investigated the effect of root system exposure to $\mathrm{Cd}$ stress in rice seedlings and showed that the root growth was enhanced as a result of $\mathrm{H}_{2} \mathrm{O}_{2}$-stimulated growth through auxin-signaling pathway. [42] Contrary to the high levels of ROS, moderate quantities of ROS can act in collaboration with auxin in environmentallystressed plant, resulting in cellular homeostasis and stability. [20]. In this regard, ROS can impact the signaling, transport, biosynthesis and metabolism of auxins [21]. Additionally, it is shown that auxin transporter mutant auxl confers to enhanced tolerance to arsenic (As(III)) in Arabidopsis thaliana by reducing levels of $\mathrm{H}_{2} \mathrm{O}_{2}$ via ROS- mediated signaling as opposed to the wild type plant [43]. On the other hand, $\mathrm{H}_{2} \mathrm{O}_{2}$ is one of the ROS compounds that can be affected by exogenous auxin [44] where auxin can control $\mathrm{H}_{2} \mathrm{O}_{2}$ formation by inducing NADPH oxidase [45], which can consequently influence superoxide production and disrupt the formation of $\mathrm{H}_{2} \mathrm{O}_{2}$ [46]. In a study on tomato root, exogenous auxin decreased $\mathrm{H}_{2} \mathrm{O}_{2}$ accumulation by prompting antioxidants that are involved in scavenging
$\mathrm{H}_{2} \mathrm{O}_{2}$ and other ROS compounds [47]. This has also been observed in a study investigating the impact of auxin signaling mutant, tirlafb2 in Arabidopsis [48]. And also in on wheat (Triticum aestivum) in which auxin triggered antioxidant activity [49-50]. Auxin homeostasis is vital to plant growth and development processes. The mechanisms involved in auxin homeostasis include; transport, conjugation degradation, deconjugation reactions and de novo biosynthesis [31]. Auxin biosynthesis is important to auxin homeostasis that occurs in meristematic parts of root tips, young plant aerial organs and in leaves at the edge of leaf mesophyll [21-51]. In auxin biosynthesis, auxin formation (indole-3-acetic acid (IAA) is synthesized from indole by tryptophan pathways including the Trp-independent pathways and the Trp-dependent synthesis [52]. These pathways alternate under stress conditions so that the Trp-independent pathways convert to the Trp-dependent IAA biosynthesis because the Trp-dependent IAA biosynthesis can effectively interact with biotic and abiotic stresses such as pathogens and wounds [31]. Conjunction mechanisms have important implications for plants in terms of transport and storage, as well as the stability of auxin [53]. They are divided into two branches including amide and ester types. In both of these types, the carboxyl group of IAA is attached to the amide-type and the carboxyl group of IAA is linked to the amino acid as an amide bond and an ester type is bound to the carboxyl group of IAA-sugar, which are metabolically involved in auxin biosynthesis [31]. Conjunction mechanism when plant is faced with heavy metal and oxidative stress can be effective in stabilizing auxin against oxidizing IAA [53]. Auxin transport is conducted by passive activity through the phloem from sources to sink sites such as the root to shoot tips. In this process, different $\mathrm{pH}$ levels in the apoplast and cytoplasm make important contributions to adjusting this efflux [54]. A reduction in $\mathrm{pH}$ level in the apoplast is an important strategy in auxin signaling mechanisms that is attained by the acidity of auxins [21]. Generally, the role of auxin under heavy metals stress can be ascribed to auxin-ROS link, which occurs by the action of special mechanisms involved in auxin homeostasis [21] and is induced by several genes involved in the adjustment of $\mathrm{H}_{2} \mathrm{O}_{2}$ levels, the regulation and stimulation of antioxidant enzymes and chlorophyll content status in plants [48]. This needs more consideration in future studies.

\section{The Tole of Cytokinins (CKs) in Response to Abiotic Stress}

Cytokinin (CKs) phytohormones are known as master regulators that play important roles in plant growth and development [55]. They are involved in many physiological processes such as cell expansion and cell division [56-57], nitrogen and phosphorus metabolism [58], water balance maintenance [59], chloroplasts integrity and senescence [60]. CKs are 
known to form $N^{6}$-substituted adenine derivatives [61]. They are associated with different hormones such as ABA [61]. CKs reduce seed dormancy while ABA reduces seed germination [23]. There are different forms of cytokinins including: 6-benzayladenine, thidiazuron, 2-isopentenyladenine and kineitin [62]. In roots and apical meristems, free cytokinins are synthesized and transferred to aerial parts with other absorbent materials (mineral elements) through the xylem. Zeatin riboside from is the most abundant $\mathrm{CK}$ in xylem exudate [9].

\section{Metal Stress}

CKs are regulatory molecules that can increase plant resistance to heavy metals through varied signaling pathways. It was shown in a study investigating the effect of endogenous CKs on arsenic stress in Arabidopsis thaliana where the reduced CK signaling and the CK-synthesizing mutant plants exhibited increased tolerance against arsenic [63]. It is reported that exogenous $\mathrm{CK}$ can elevate plant resistance to metal stress [22-63]. The protective role of synthetic cytokinins is attributed to the presence of kinetin group in its molecular structure that can induce plant antioxidant defense system [60]. It is reported that kinetin can ameliorate reactive oxygen species (ROS) [64]. One of the CK mechanisms under heavy metal stress conditions is the alteration of the level of CK. It is reported that with the excess of heavy metals, the amount of CK decreases to improve plant overall efficiency to cope with the stress [61-65]. One of the reasons for the reduced $\mathrm{CK}$ content may be the rising accumulation of ABA in stress conditions, which can activate special enzymes involved in CK degradation and preclude the expression of genes responsible for the control of $\mathrm{CK}$ biosynthesis [22]. ABA processes such as catabolism, synthesis, transport, and conjugation can influence cytokinin metabolism and change CK concentration in stress conditions [66]. However, the efficiency of $\mathrm{CK}$ in the interaction with ROS is concentrationdependent [67]. CK can ameliorate ROS by reducing cellular ROS concentration. This was observed by treating wheat leaves with the synthetic cytokinin 6-benzyladenine (BAP) in dark stress conditions [60]. The genes necessary for $\mathrm{CK}$ metabolism can regulate stress in some processes that may lead to a reduction in CK content [68]. Additionally, it has been reported that exogenous $\mathrm{CK}$ can ameliorate other various abiotic stress factors. The studies indicate that exposure of drought-stressed maize plants to BAP could improve the crop growth by increasing the chlorophyll content [69]. In another study, by spraying the kinetin on wheat leaves subjected to drought stress, the exogenous CK had positively influenced cellular ion homeostasis and improved membrane injury [70]. However, in transgenic plants, some reports suggest that increasing intensity of abiotic stress may lead to increased CK levels in plants [71]. The mechanism involved is as follows: In response to low water stress, there is an increase in the synthesis of cytokinin. This leads to changes in plant metabolism that can reduce shoot growth and postpone plant defense activation to preserve plants under restricted water conditions [72-73].

\section{The Role of Ethylene (ET) in Response to Abiotic Stress}

Ethylene (ET) is a gaseous phytohormone that has an essential role in many metabolic and developmental processes of plant including the senescence of flowers, abscission of petals and leaves, as well as fruit ripening. It also acts as a regulatory hormone during plant stress responses [24-74-75]. The rate of ET synthesis increases with enhancement of biotic and abiotic stresses [76]. This increase is associated with decline in plant growth and development, which is the first ET-induced line of response when plant faces environmental stressors [77]. The mechanism of action of ET to ameliorate heavy metal stress is attributable to gene expression that occurs upon the onset of metal-induced stress, leading to the production of increased levels of $A C S$ and $A C O$ proteins. These two proteins are involved in ethylene biosynthesis. This process increases the generation of ethylene in plants, therefore leading to the protective role of ethylene in plants [76-77]. Many studies confirm the role of heavy metals in inducing the synthesis of these proteins, which has been shown with chromium $(\mathrm{Cr})$ in rice inducing the expression of the genes ACS1, ACS2, ACO4, and ACO5 [78-79]; with copper $(\mathrm{Cu})$ in potatoes and tobacco inducing the expression of the gene ACS [2]; and with $\mathrm{Cd}$ in Arabidopsis thaliana stimulating the biosynthesis of ACC and ACS6 [77]. Moreover, the EIN2 genes have an important role in generating ethylene so that these genes are involved in ethylene signaling and transduction pathways. The heavy metal stress can activate ethylene transducer, resulting in enhancement of transcript levels of EIN2 which is reflected by an increase in the ethylene content in plants. This has been shown in Arabidopsis seedlings exposed to lead $(\mathrm{Pb})$, which resulted in the improved plant tolerance to $\mathrm{Pb}$ [80]. On the other hand, exogenous ACC appears to be effective in enhancing plant heavy metal tolerance by increasing production of ethylene, which per se can raise antioxidant defense levels. Arabidopsis thaliana under $\mathrm{Cd}$ stress treated with exogenous ACC exhibited increased levels of ethylene, leading to enhanced SOD activity and improved root growth [81]. Ethylene has also been found essential for sulfur-mediated alleviation of $\mathrm{Cd}$ in mustard [82]. Concomitant induction of ethylene or its precursor ACC and chemical compounds such as hydrogen peroxide has been noted under heavy metal stress in various plants such as tomato and chickpea [83-84]. In a study with Cd-stressed potato, a synergistic action between ROS and $A C C$ was observed, which was indicative of $\mathrm{H}_{2} \mathrm{O}_{2}$ and ethylene interplay [85]. It is shown that exogenous $\mathrm{H}_{2} \mathrm{O}_{2}$ can lead to increased ACC production in stress conditions [86]. It is reported that gene expression of 
the ethylene receptor has an important role in quenching ROS compounds arising from osmotic stress [87-88]. In a study on Arabidopsis thaliana, osmotic and salt stress led to the adjustment of gene expression of the ethylene receptor with the expression of gene ETR1 at both the mRNA and protein levels [89]. In addition, functional potency of mutant plants affects stress. In the A. thaliana functional mutant etr1-7, there is more potential to ameliorate salt stress than functional mutant etr1-1(ethylene insensitivity) [90]. Besides, in another study, a similar result indicated the regulatory impact of ethylene receptor on oxidative stress levels [91]. However, the threshold concentration of ACC is low in plants with the abundance of ACC synthesis. Ethylene appears to play a dual role in plant response to abiotic stresses, which can be interpreted as either alleviatory or aggravating [12-64].

\section{The Role of Abscisic Acid (ABA) in Response o Abiotic Stress}

Abscisic acid (ABA) is a multifunctional phytohormone with vital roles in the plant life cycle [92]. ABA is involved in many physiological and metabolic processes such as stomatal closure, seed dormancy, seed germination and regulates many growth and development processes in plants like fruit ripening and leaf abscission [4]. This molecule is a sesquiterpene, which consists of multi-functional parts [93]. Signaling paths of ABA include PP2C, SnRK2, and PYL/PYR/ RCAR, which play an important role in complex ABA regulation [94]. Generally, transduction of ABA signals happens through fourteen genes. These genes include two SnRK2, three PP2C, and nine PYL genes [2]. ABA is a signaling messenger molecule which is indirectly stimulated by plant defense system in response to the generation of ROS [46]. Changes in the amount of ABA content happen through a number of mechanisms, including $\mathrm{ABA}$ transport, $\mathrm{ABA}$ catabolism and $\mathrm{ABA}$ synthesis as well as the reaction with glucose via conjugation and deconjugation mechanisms [3]. ABA synthesis occurs in chloroplasts through two chemical pathways [95] including degradation of the carotenoid violaxanthin and catalysis of neoxanthin into xanthoxin [95-4]. ABA is also synthesized by de novo (de novo biosynthesis in ABA) during the drying process [93]. which takes place in plant organs including terminal buds and roots [96]. The ABA conjugation and deconjugation processes has a role in regulating ABA levels and continual modulation of glucose levels. ABA conjugation results in the permanent deactivation of ABA and its vacuolar repository [3]. However, the role of glycosyltransferase genes is considered to be in the production, regulation and storage levels of ABA. This can be attributed to the important role of glycosyltransferase genes in controlling the mechanisms involved in the alteration of ABA levels [97-98]. For many years, researchers thought that mechanisms involved in ABA transfer were associated with $\mathrm{pH}$ gradients in intercellular organs and between symplast and apoplast [99]. However, the recent studies show that AtBCG25 and AtBCG40 transporters have an important role in transferring $\mathrm{ABA}$ to sink sites and guard cells, which is the indicative of the role of the AtBCG type in the movement of ABA in cells [100]. This accumulation of ABA and ABA synthesis in guard cells might be a mechanism for regulating stomatal closure during stress [101].

\section{Metal Stress}

ABA can lead to reduced translocation of heavy metals from root to shoot and the accumulation of heavy metals in roots. The oxidative stress triggered by the excess heavy metals causes the amount of ABA concentration in the plant to increase [2], which can play an important role in the stimulation of antioxidants and increasing their protective capacity. This phenomenon has been reported by many studies conducted with different heavy metals on plants such as seaweed species, [102], and rice [103]. In this process, ABA signals activate the expression of genes involved in antioxidant enzymes and non-enzyme activity. In many plant species, ZEP is the gene involved in ABA biosynthesis and ZEP gene expression is higher in leaves than in other parts of plant organs [104] Which has reported in one study on Grapevine (Vitis vinifera L.) [105]. The results obtained by a study on rice seedlings indicated that the exogenous levels of ABA decreased Cd uptake by the plant [106]. Exogenous ABA can alter concentration of metal ions within plant body and contribute to metal detoxification by regulating the expression of some key genes involved in metal absorption and transfer. In a study, exogenously applied ABA mitigated zinc toxicity in Populus $\times$ canescens by reducing the metal uptake and accumulation [107]. This was attributed to the modulation of transcript expression levels responsible for $\mathrm{Zn}$ absorption by ABA. On the other hand, ABA is able to alleviate conditions arising from heavy-metal induced dehydration in plants. The excess of heavy metals leads to a disturbance in photosynthetic indexes, a decrease in net photosynthesis and transpiration imbalance [108] and a disruption of ion permeability in guard cells, eventually leading to disturbed water balance throughout the plant [109110]. Hence, heavy metal stress indirectly induces drought conditions in plants [111]. ABA regulates stomata closure when the plant does not require much $\mathrm{CO}_{2}$ and when it faces drought stress and cannot afford to lose more water [112]. In these conditions, ABA is produced from roots and transferred to guard cells via xylem sap leading to stomata closure in leaves [111]. The regulation of stomata can preserve water balance and improve drought stress intensity caused by metal toxicity in the plant [112]. 


\begin{tabular}{|c|c|c|c|c|c|c|c|c|c|c|c|c|c|c|c|c|c|c|}
\hline 岕" & $\stackrel{\Xi}{\varrho}$ & $\stackrel{\bar{m}}{\Xi}$ & $\underset{\Xi}{\Xi}$ & $\stackrel{\infty}{\Xi}$ & $\stackrel{\varpi}{\Xi}$ & $\vec{g}$ & $\stackrel{\Xi}{\Xi}$ & $\Xi$ & $\bar{g}$ & $\stackrel{\infty}{\Xi}$ & $\stackrel{\bar{\Xi}}{\Xi}$ & 守 & 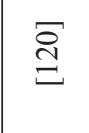 & 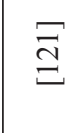 & $\widetilde{\Xi}$ & $\underset{\mathscr{D}}{\widetilde{\infty}}$ & $\stackrel{\widetilde{\Xi}}{\Xi}$ & 寻 \\
\hline 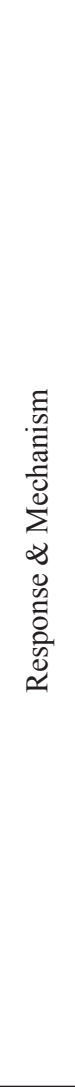 & 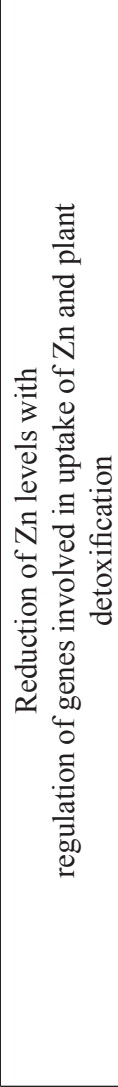 & 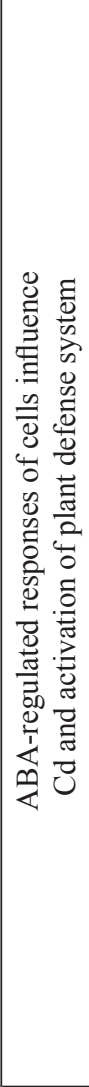 & 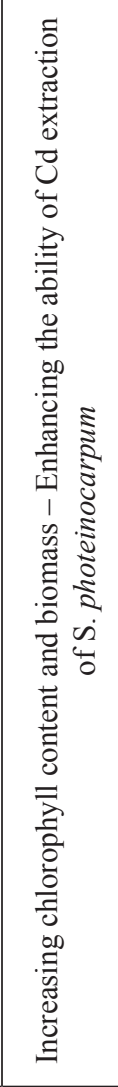 & 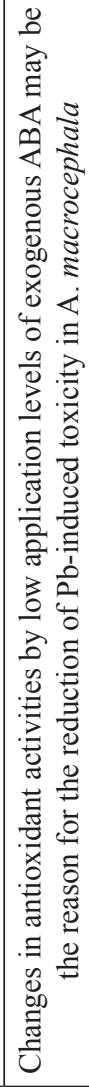 & 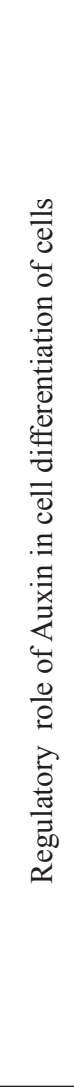 & 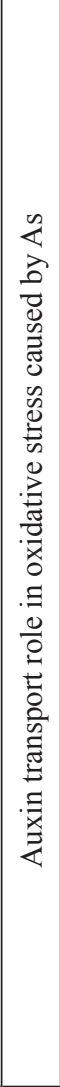 & 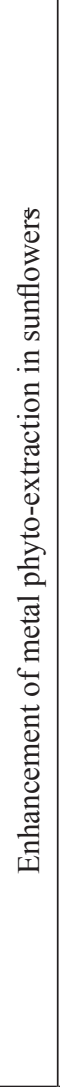 & 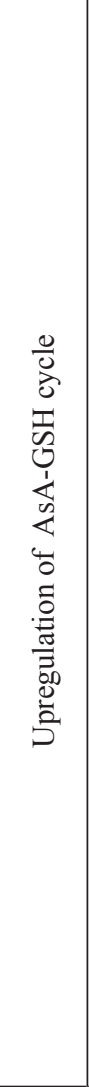 & 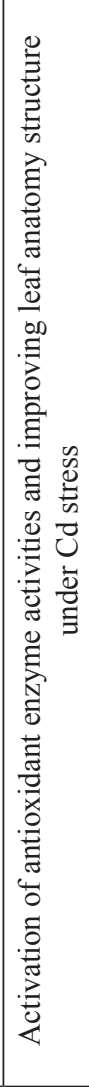 & 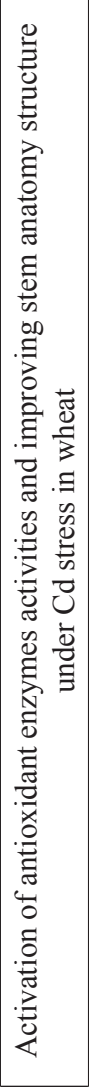 & 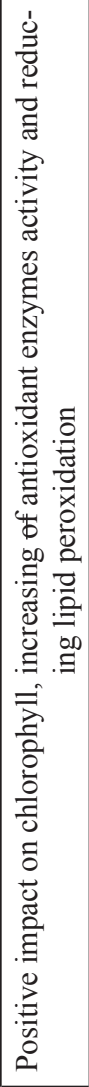 & 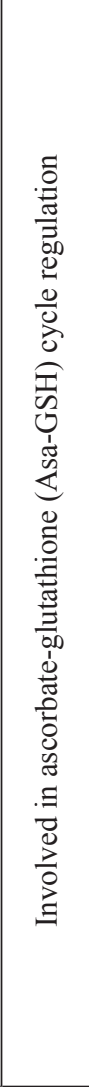 & 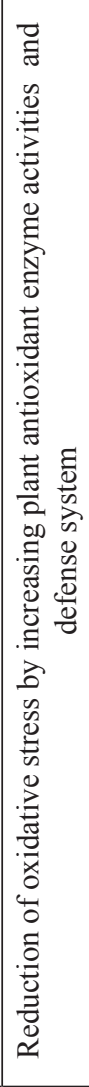 & 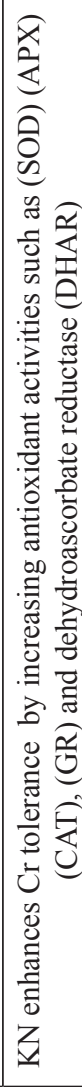 & 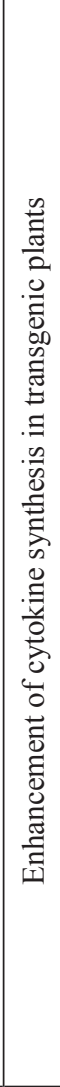 & 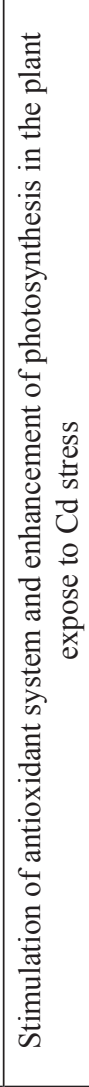 & 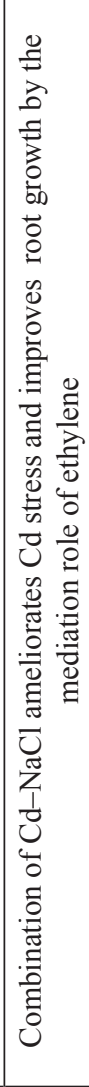 & 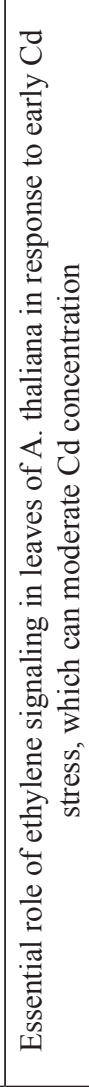 \\
\hline 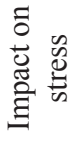 & + & + & + & + & + & + & + & + & + & + & + & + & + & + & + & + & + & + \\
\hline 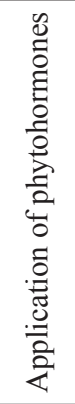 & 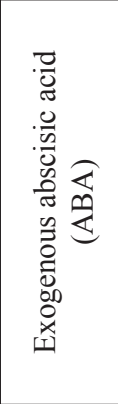 & 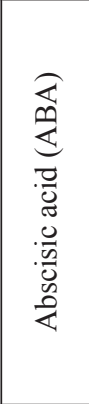 & 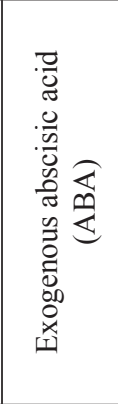 & 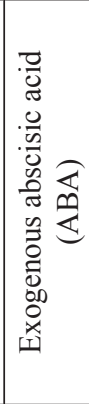 & 䍗 & 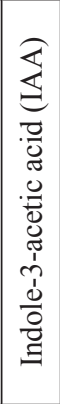 & 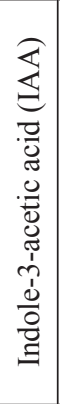 & 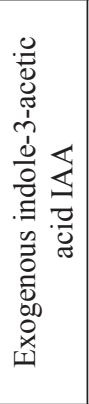 & 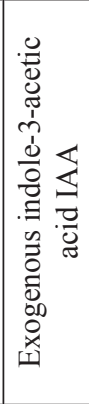 & 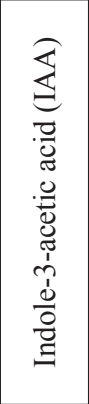 & 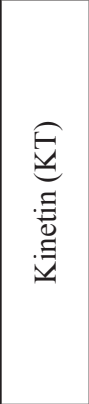 & 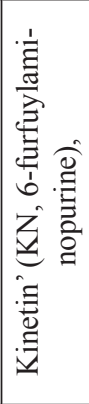 & 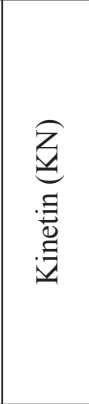 & 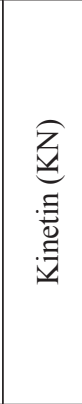 & 咅 & 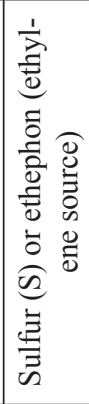 & 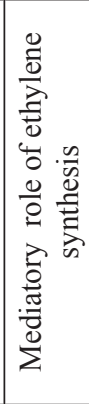 & 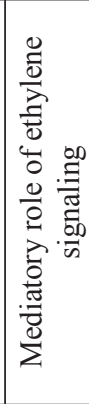 \\
\hline 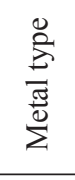 & งี & $\bar{J}$ & $\tilde{U}$ & $\overrightarrow{2}$ & 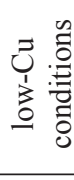 & $\sum^{2}$ & 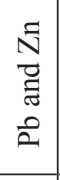 & $\tilde{J}$ & $\bar{U}$ & $\tilde{U}$ & $z^{2}$ & $\bar{J}$ & ڤે & $\sum_{U}$ & 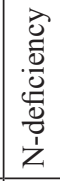 & $\vec{U}$ & $\bar{U}$ & $\vec{U}$ \\
\hline$\frac{\vec{U}}{2}$ & 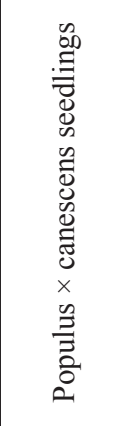 & 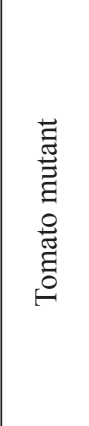 & 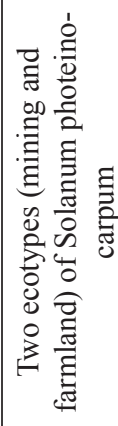 & 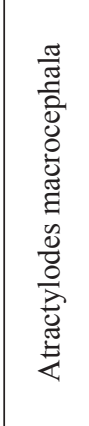 & 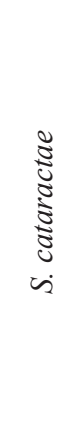 & 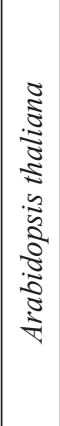 & 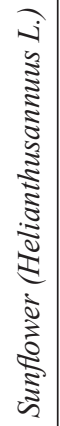 & 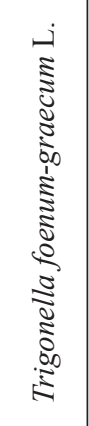 & $\begin{array}{l}\vec{J} \\
\frac{D}{3}\end{array}$ & $\begin{array}{l}\vec{J} \\
\sum_{3}^{5}\end{array}$ & 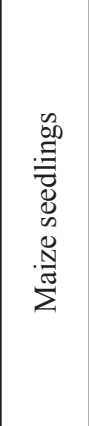 & 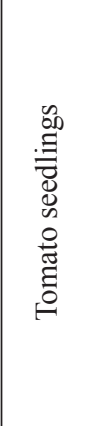 & 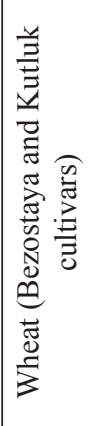 & 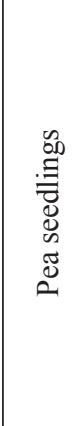 & 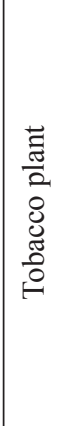 & 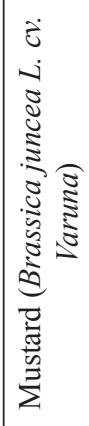 & 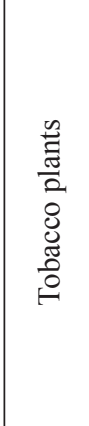 & 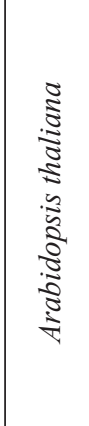 \\
\hline
\end{tabular}




\section{Conclusion}

ROS produced under various biotic or abiotic stress factors can interact with hormonal signaling pathways. There are four different phytohormones: abscisic acid (ABA), auxin (IAA), cytokinins (CKs), and ethylene (ET), which play vital roles in stress conditions. They contribute to the generation of essential enzymes required for cell protection and preservation of proteins and lipids. ABA acts as a regulator of excessive metal with a role as a signaling molecule. Upon the onset of heavy metal stress in plants, ABA levels start increasing, which leads to establishing a signaling communication and encoding of genes associated with plant antioxidant enzyme and defense systems. In this process, ABA signals activate the expression of genes responsible for the bio-synthesis of plant antioxidant enzymes and non-enzyme components. In addition, ABA, as a signaling messenger molecule, is stimulated by plant defense responses to the generation of ROS. On the other hand, ABA can significantly impede translocation of heavy metal ions from root to shoot, resulting in accumulation of heavy metals in root. The auxin -mediated response to heavy metal stress in plant is related to the reciprocity between $\mathrm{H}_{2} \mathrm{O}_{2}$ and auxin homeostasis. ROS signaling acts as a mediator in plant growth and development assisted by auxin. ROS signaling can impact signaling, transport, biosynthesis, and metabolism of auxins. Additionally, exogenous auxin can disturb $\mathrm{H}_{2} \mathrm{O}_{2}$ formation by inducing NADPH oxidase and activating antioxidant defense mechanisms. The enhancement of ethylene production is a warning alarm of a critical situation of stress in the plant. ET biosynthesis and signaling are influenced by the status of nutrients in plants, which in turn is impacted by ROS level. The main mechanism for ET regulation of metal stress is the interaction between ACC, ROS signaling and $\mathrm{H}_{2} \mathrm{O}_{2}$ production. It seems that there is a relationship in $\mathrm{ABA} / \mathrm{CK}$ ratio such that with an accumulation of ABA, the level of $\mathrm{CKs}$ is reduced. This process leads to increased apical dominance and to positive effects on stomatal aperture and enhanced plant defense resistance. On the other hand, exogenous CK signaling can reduce heavy metals stress by affecting ROS, resulting in decreased ROS production. Generally, CKs can ameliorate heavy metal stresses via some pathways involving exogenous $\mathrm{CK}$, CK metabolism, and CK signaling. Below, Table 1 demonstrates the impact of phytohormones on different plant species subjected to various heavy metals by describing the related mechanisms, which builds an evidence-based argument for the main text. It seems that the phytohormones act as signaling molecules and are in the interaction with redox signaling during metal exposure. This can result in the activation of gene expression involved in plant defense mechanisms. Hence, cross-linked ROS and hormonal signaling networks contribute to increased plant resistance under stress conditions.

\section{Acknowledgments}

This work was supported by the financial support provided by Nanjing Forestry University (Start-Up Research Fund) and Bamboo Research Institute for the current study. Special Fund for this work was supported by National Key Research \& Development Program of China (Integration and Demonstration of Valued \& Efficiency -increased Technology across the Industry Chain for Bamboo, 2016 YFD0600901)

\section{Conflict of Interests}

The authors declare that there is no conflict of interests regarding the publication of this paper.

\section{References}

1. VOB U., BISHOPP A., FARCOT E., BENNETT M.J. Modelling hormonal response and development. Trends Plant Sci. 19, 311, 2014.

2. BÜCKER-NETO L., PAIVA ALS., MACHADO RD., ARENHART RA., MARGIS-PINHEIRO M. Interactions between plant hormones and heavy metals responses. Genet Mol Biol. 40, 373, 2017.

3. VERSLUES P.E. ABA and cytokinins: challenge and opportunity for plant stress research. Plant Mol Biol. 91 (6), 629, 2016.

4. VISHWAKARMA K., UPADHYAY N., KUMAR N., YADAV G., SINGH J., MISHRA RK., KUMAR V., VERMA R., UPADHYAY RG., PANDEY M., SHARMA S. Abscisic Acid Signaling and Abiotic Stress Tolerance in Plants: A Review on Current Knowledge and Future Prospects. Front Plant Sci. 8, 161, 2017.

5. JONES A.M. A new look at stress: abscisic acid patterns and dynamics at high-resolution. New Phytol. 210 (1), 38, 2015.

6. EGAMBERDIEVA D., WIRTH S.J., ALQARAWI A.A., ABD_ALLAH E.F., HASHEM A. Phytohormones and Beneficial Microbes: Essential Components for Plants to Balance Stress and Fitness. Front Microbiol, 8, 2104, 2017.

7. ÇAKMAKÇI R., MOSBER G., MILTON AH., ALATÜRK F., ALI B. The Effect of Auxin and AuxinProducing Bacteria on the Growth, Essential Oil Yield, and Composition in Medicinal and Aromatic Plants. Curr Microbiol, 77, 564, 2020.

8. PÉRET B., SWARUP K., FERGUSON A., SETH M., YANG Y., DHONDT S., JAMES N., CASIMIRO I., PERRY P., SYED A., YANG H., REEMMER J., VENISON E., HOWELLS C., PEREZ-AMADOR M.A., YUN J., ALONSO J., BEEMSTER GT., LAPLAZE L., MURPHY A., BENNETT M.J., NIELSEN E., SWARUP R. AUX/LAX genes encode a family of auxin influx transporters that perform distinct functions during Arabidopsis development. Plant Cell. 24, 2874, 2012.

9. MANGIERI M.A., HALL A.J., STRIKER G.G., CHIMENTI C.A. Cytokinins: A key player in determining differences in patterns of canopy senescence in StayGreen and Fast Dry-Down sunflower (Helianthus annuus L.) hybrids. Eur J Agron. 86, 60, 2017. 
10. AKHTAR S.S., MEKUREYAW M.F., PANDEY C., ROITSCH T. Role of Cytokinins for Interactions of Plants With Microbial Pathogens and Pest Insects. Front. Plant Sci. 10, 1777, 2020.

11. O'BRIEN J.A., BENKOVÁ E. Cytokinin cross-talking during biotic and abiotic stress responses. Front. Plant Sci. 4, 451, 2013.

12. SINGH R.P., SHELKE G.M., KUMAR A., JHA P.N. Biochemistry and genetics of ACC deaminase: a weapon to "stress ethylene" produced in plants. Front Microbiol. 6, 937, 2015.

13. VAN DE POEL B., VAN DER STRAETEN D. 1-aminocyclopropane-1-carboxylic acid (ACC) in plants: more than just the precursor of ethylene!. Front Plant Sci. 5, 640, 2014

14. SCHELLINGEN K., VAN DER STRAETEN UGENT D., REMANS T., LOIX L., VANGRONSVELD J., CUYPERS A. Ethylene biosynthesis is involved in the early oxidative challenge induced by moderate $\mathrm{Cd}$ exposure in Arabidopsis thaliana. Environ. Exp. Bot. 117, 1, 2015.

15. SCHELLINGEN K., VAN DER STRAETEN D., REMANS T., VANGRONSVELD J., KEUNENA E., CUYPERS A. Ethylene signalling is mediating the early cadmium-induced oxidative challenge in Arabidopsis thaliana Plant Sci. 239, 137, 2015.

16. KEUNEN E., SCHELLINGEN K., VANGRONSVELD J., CUYPERS A. Ethylene and Metal Stress: Small Molecule, Big Impact. Els Keunen. Front Plant Sci. 7, 23, 2016.

17. KUMAR M.N., VERSLUES P.E. Stress physiology functions of the Arabidopsis histidine kinase cytokinin receptors. Physiol Plant. 154, 369, 2015.

18. WANG J.C., CHEN J., PAN K.W. Effect of exogenous abscisic acid on the level of antioxidants in Atractylodes macrocephala Koidz under lead stress. Environ Sci Pollut Res Int. 20, 1441, 2013.

19. FEDIUC E., LIPS S.H., ERDEI L. O-Acetylserine (thiol) lyase activity in Phragmites and Typha plants under cadmium and $\mathrm{NaCl}$ stress conditions and the involvement of ABA in the stress response. J. Plant Physiol. 162, 865, 2005.

20. KRISHNAMURTHY A., RATHINASABAPATHI B. Oxidative stress tolerance in plants.Novel interplay between auxin and reactive oxygen species signaling. Plant Signal Behav. 8, 10, 2013.

21. TOGNETTI V.B., MÜHLENBOCK P., VAN BREUSEGEM F. Review Stress homeostasis - the redox and auxin perspective. Plant Cell Environ. 35 (2), 321, 2012.

22. VESELOV D.S., KUDOYAROVA G.R., KUDRYAKOVA N.V., KUSNETSOV V.V. Role of Cytokinins in stress Resistance of plants. Russ. J. Plant Physiol. 64, 15, 2017.

23. FAHAD S., HUSSAIN S., MATLOOB A., KHAN FA., KHALIQ A., SAUD S., HASSAN S., SHAN D., KHAN F., ULLAH N., FAIQ M., KHAN M.R., TAREEN A.K., KHAN A., ULLAH A., ULLAH N., HUANG J.L. Phytohormones and plant responses to salinity stress: a review. Plant Growth Regul. 75, 391, 2015.

24. WANI S.H., KUMAR V., SHRIRAM V., KUMAR SAHD $S$. Phytohormones and their metabolic engineering for abiotic stress tolerance in crop plants. The Crop Journal. 4, 162, 2016.

25. KHAN N.A., KHAN M.I.R., FERRANTE A., POOR P. Editorial: Ethylene: A Key Regulatory Molecule in Plant. Front Plant Sci. 8, 1782, 2017.
26. DUBOIS M., VAN DEN BROECK L., INZÉ D. The Pivotal Role of Ethylene in Plant Growth. Trends Plant Sci. 23 (4), 311, 2018.

27. SHARMA A., KUMAR V., PREET SINGH SIDHU G., KUMAR R., KAUR KOHLI S., YADAV P., KAPOOR D., BALI AS., SHAHZAD B., KHANNA K., KUMAR S., KUMAR THUKRAL A., BHARDWAJ R. Abiotic stress management in plants: Roles of Ethylene: In Book Title, Molecular Plant Abiotic Stress: Biology and Biotechnology.; Roychoudhury A., Tripath D. John Wiley \& Sons, Ltd. 185. 2019.

28. ALI S., KIM W.C. Plant Growth Promotion Under Water: Decrease of Waterlogging-Induced ACC and Ethylene Levels by ACC Deaminase-Producing Bacteria. Front Microbiol. 9, 1096, 2018.

29. ARRAES F.B., BENEVENTI M.A., LISEI DE SA M.E., PAIXAO J.F., ALBUQUERQUE E.V., MARIN S.R., PURGATTO E., NEPOMUCENO A.L., GROSSI-DE-SA M.F. Implications of ethylene biosynthesis and signaling in soybean drought stress tolerance. BMC Plant Biol. 3 (15), 213, 2015.

30. MROUE S., SIMEUNOVIC A., ROBERT H.S. Auxin production as an integrator of environmental cues for developmental growth regulation. J Exp Bot. 69 (2), 201, 2018.

31. WOODWARD A.W., BARTEL B. Auxin: regulation, action, and interaction. Ann Bot. 95, 707, 2005.

32. CAO X., YANG H., SHANG C., MA S., LIU L., CHENG J. The Roles of Auxin Biosynthesis YUCCA Gene Family in Plants. Int J Mol Sci. 16, 20 (24). Pii: E6343, 2019.

33. KORASICK D.A., ENDERS T.A., STRADER L.C. Auxin biosynthesis and storage forms. J Exp Bot. 64 (9), 2541, 2013.

34. TAYLOR-TEEPLES M., LANCTOT A., NEMHAUSER J.L. As above, so below: Auxin's role in lateral organ development. Dev Biol. 419 (1), 156, 2016.

35. BRUMOS J., ALONSO J.M., STEPANOVA A.N. Genetic aspects of auxin biosynthesis and its regulation. Physiol Plant. 151 (1), 3, 2014.

36. CHO M., LEE S.H., CHO H.T. P-glycoprotein 4 displays auxin efflux transporter-like action in Arabidopsis root hair cells and tobacco cells. Plant Cell. 19, 3930, 2007.

37. SWARUP R., BHOSALE R. Developmental Roles of AUX1/LAX Auxin Influx Carriers in Plants. Front Plant Sci. 10, 1306, 2019.

38. FUKUI K., HAYASHI K.I. Manipulation and Sensing of Auxin Metabolism, Transport and Signaling. Plant Cell Physiol. 159 (8), 1500, 2018.

39. BHOSALE R., GIRI J., PANDEY B.K., GIEHL R.F.H., HARTMANN A., TRAINI R., TRUSKINA J., LEFTLEY N., HANLON M., SWARUP K., RASHED A., VOSS U., ALONSO J., STEPANOVA A., YUN J., LJUNG K., BROWN K.M., LYNCH JP., DOLAN L., VERNOUX T., BISHOPP A., WELLS D., VON WIRÉN N., BENNETT M.J., SWARUP R. A mechanistic framework for auxin dependent Arabidopsis root hair elongation to low external phosphate. Nat Commun. 12,9 (1), 1409, 2018.

40. YU C., SUN C., SHEN C., WANG S., LIU F., LIU Y., CHEN Y., LI C., QIAN Q., ARYAL B., GEISLER M., JIANG DE A., QI Y. The auxin transporter, OsAUX1, is involved in primary root and root hair elongation and in $\mathrm{Cd}$ stress responses in rice (Oryza sativa L.). Plant J. 83 (5), 818, 2015.

41. KRIEGER G., SHKOLNIK D., MILLER G., FROMM H. Reactive Oxygen Species Tune Root Tropic Responses. Plant Physiol. 172 (2), 1209, 2016. 
42. ZHAO FY., HAN M.M., ZHANG SY., WANG K., ZHANG C.R., LIU T., LIU W. Hydrogen peroxide-mediated growth of the root system occurs via auxin signaling modification and variations in the expression of cell-cycle genes in rice seedlings exposed to cadmium stress. J Integr Plant Biol. 54, 991, 2012.

43. KRISHNAMURTHY A., RATHINASABAPATHI B. Auxin and its transport play a role in plant tolerance to arsenite-induced oxidative stress in Arabidopsis thaliana. Plant Cell Environ. 36 (10), 1838, 2013.

44. PEER W.A., CHENG Y., MURPHY A.S. Evidence of oxidative attenuation of auxin signalling. J Exp Bot. 64 (9), 2629, 2013.

45. IVANCHENKO M.G., DEN OS D., MONSHAUSEN G.B., DUBROVSKY J.G., BEDNÁROVÁ A., KRISHNAN N. Auxin increases the hydrogen peroxide $\left(\mathrm{H}_{2} \mathrm{O}_{2}\right)$ concentration in tomato (Solanum lycopersicum) root tips while inhibiting root growth. Ann Bot. 112 (6), 1107, 2013.

46. XIA X.J., ZHOU Y.H., SHI K., ZHOU J., FOYER C.H., YU JQ. Interplay between reactive oxygen species and hormones in the control of plant development and stress tolerance. J Exp Bot. 66 (10), 2839, 2015.

47. TYBURSKI J., DUNAJSKAM K., MAZUREK P., PIOTROWSKA B., TRETYN A. Exogenous auxin regulates $\mathrm{H}_{2} \mathrm{O}_{2}$ metabolism in roots of tomato (Lycopersicon esculentum Mill.) seedlings affecting the expression and activity of CuZn-superoxide dismutase, catalase, and peroxidase. Acta Physiol Plant. 31, 249, 2009.

48. IGLESIAS M.J., TERRILE M.C., BARTOLI C.G., D'IPPÓLITO S., CASALONGUÉ C.A. Auxin signaling participates in the adaptative response against oxidative stress and salinity by interacting with redox metabolism in Arabidopsis. Plant Mol Biol. 74 (3), 215, 2010.

49. AGAMI R.A., MOHAMED G.F. Exogenous treatment with indole-3- acetic acid and salicylic acid alleviates cadmium toxicity in wheat seedlings. Ecotoxicol. Environ. Saf. 94, 164, 2013.

50. ZHU X.F., WANG Z.W., DONG F., LEI G.J., SHI Y.Z., LI G.X., ZHENG S.J. Exogenous auxin alleviates cadmium toxicity in Arabidopsis thaliana by stimulating synthesis of hemicellulose 1 and increasing the cadmium fixation capacity of root cell walls. J. Hazard. Mater. 263, 398, 2013.

51. PINON V., PRASAD K., GRIGG SP., SANCHEZ-PEREZ G.F., SCHERES B. Local auxin biosynthesis regulation by PLETHORA transcription factors controls phyllotaxis in Arabidopsis. Proc Natl Acad Sci U S A. 15, 110 (3), 1107, 2013.

52. ZHAO Y. Auxin biosynthesis and its role in plant development. Annual Review of Plant Biology. 61, 49, 2010.

53. MA Q., GRONES P., ROBERT S. Auxin signaling: a big question to be addressed by small molecules. J Exp Bot. 69 (2), 313, 2018.

54. ROBERT H.S., FRIML J. Auxin and other signals on the move in plants. Nature Chemical Biology. 5, 325, 2009.

55. KANG N.Y., CHO C., KIM N.Y., KIM J. Cytokininreceptor-dependent and receptor-independent path ways in the dehydration response of Arabidopsis thaliana. J. Plant Physiol. 169, 1382, 2012.

56. NANDA A.K., MELNYK C.W. The role of plant hormones during grafting. J Plant Res. 131 (1), 49, 2018.
57. TAKATSUKA H., UMEDA M. Hormonal control of cell division and elongation along differentiation trajectories in roots. J Exp Bot. 65 (10), 2633, 2014.

58. KUDOYAROVA G.R., DODD I.C., VESELOV D.S., ROTHWELL S.A., VESELOV S.Y. Common and specific responses to availability of mineral nutrients and water, J. Exp. Bot. 66, 2133, 2015.

59. PREROSTOVA S., DOBREV PI., GAUDINOVA A., KNIRSCH V., KÖRBER N., PIERUSCHKA R., FIORANI F., BRZOBOHATÝ B., ČERNÝ M., SPICHAL L., HUMPLIK J., VANEK T., SCHURR U., VANKOVA R. Cytokinins: Their Impact on Molecular and Growth Responses to Drought Stress and Recovery in Arabidopsis. Front Plant Sci. 9, 655, 2018.

60. HÖNIG M., PLÍHALOVÁ L., HUSIČKOVÁ A., NISLER J., DOLEŽAL K. Role of Cytokinins in Senescence, Antioxidant Defence and Photosynthesis. Int J Mol Sci, 19 (12) 4045, 2018.

61. HWANG I., SHEEN J., MULLER B. Cytokinin signaling networks, Annu. Rev. Plant Biol 63, 353, 2012.

62. BEKIRCAN T., YAŞAR A., YILDIRIM S., SÖKMEN M., SÖKMEN A. Effect of cytokinins on in vitro multiplication, volatiles composition and rosmarinic acid content of Thymus leucotrichus Hal. Shoots. 3 Biotech. 8 (3), 180, 2018.

63. MOHAN TC., CASTRILLO G., NAVARRO C., ZARCO-FERNÁNDEZ S., RAMIREDDY E., MATEO C., ZAMARREÑO A.M.L., PAZ-ARES J., MUÑOZ R., GARCÍA-MINA J.M., HERNÁNDEZ L.E., SCHMÜLLING T., LEYVA A. Cytokinin Determines Thiol-Mediated Arsenic Tolerance and Accumulation. Plant Physiol. 171 (2), 1418, 2016.

64. SINGH S., SINGH A., SRIVASTAVA P.K., PRASAD S.M. Cadmium toxicity and its amelioration by kinetin in tomato seedlings vis-à-vis ascorbate-glutathione cycle. J Photochem Photobiol B. 178, 76, 2018.

65. KOHLI A., SREENIVASULU N., LAKSHMANAN P., KUMAR P.P. The phytohormone crosstalk paradigm takes center stage in understanding how plants respond to abiotic stresses, Plant Cell Rep. 32, 945, 2013.

66. FRÉBORT I., KOWALSKA M., HLUSKA T., FRÉBORTOVÁ J., GALUSZKA P. Evolution of cytokinin biosynthesis and degradation. J Exp Bot. 62, 2431, 2011.

67. PILARSKA M., SKOWRON E., PIETRAŚ R., KRUPINSKA K., NIEWIADOMSK E. Changes in lipid peroxidation in stay-green leaves of tobacco with senescence-induced synthesis of cytokinins. Plant Physiol Biochem. 118, 161, 2017.

68. BRENNER W.G., RAMIREDDY E., HEYL A., SCHMÜLLING T. Gene regulation by cytokinin in Arabidopsis. Front Plant Sci. 3, 8, 2012.

69. ALI Z., BASRA SMA., MUNIR H., MAHMOOD A., YOUSAF S. Mitigation of drought stress in maize by natural and synthetic growth promoters. J. Agric. Soc. Sci. 7, 56, 2011.

70. AHANGER M.A., ALYEMENI M.N., WIJAYA L., ALAMRI S.A., ALAM P., ASHRAF M., AHMAD P. Potential of exogenously sourced kinetin in protecting Solanum lycopersicum from $\mathrm{NaCl}$-induced oxidative stress through up-regulation of the antioxidant system, ascorbate-glutathione cycle and glyoxalase system. PLoS One, 13 (9), e0202175, 2018.

71. RIVERO R.M., GIMENO J., VAN DEYNZE A., WALIA H., BLUMWALD E. Enhanced cytokinin synthesis in 
tobacco plants expressing P-SARK:IPT prevents the degradation of photosynthetic protein complexes during drought. Plant Cell Physiol. 51, 1929, 2010.

72. KANT S., BURCH D., BADENHORST P., PALANISAMY R., MASON J., SPANGENBERG G. Regulated expression of a cytokinin biosynthesis gene ipt delays leaf senescence and improves yield under rainfed and irrigated conditions in canola (Brassica napus L.). PLoS One. 10 (1), e0116349, 2015.

73. MACKOVÁ H., HRONKOVÁ M., DOBRÁ J., TUREČKOVÁ V., NOVÁK O., LUBOVSKÁ Z., MOTYKA V., HAISEL D., HÁJEK T., PRÁŠIL I.T., GAUDINOVÁ A., ŠTORCHOVÁ H., GE E., WERNER T., SCHMÜLLING T., VANKOVÁ R. Enhanced drought and heat stress tolerance of tobacco plants with ectopically enhanced cytokinin oxidase/dehydrogenase gene expression. J Exp Bot. 64, 2805, 2013.

74. GAMALERO E., GLICK B.R. Ethylene and abiotic stress tolerance in plants P. Ahmed, M.N.V. Prasad (Eds.), Environmental Adaptations and Stress Tolerance of Plants in the Era of Climate Change, Springer, New York (2012), 395, 2012.

75. GROEN S.C., WHITEMAN N.K. The evolution of ethylene signaling in plant chemical ecology J. Chem. Ecol, 40, 700, 2014.

76. KHAN M.I., NAZIR F., ASGHER M., PER T.S., KHAN N.A. Selenium and sulfur influence ethylene formation and alleviate cadmium-induced oxidative stress by improving proline and glutathione production in wheat. J Plant Physiol. 173, 9, 2015.

77. SCHELLINGEN K., VAN DER STRAETEN D., VANDENBUSSCHE F., PRINSEN E., REMANS T., VANGRONSVELD J., CUYPERS A. Cadmium-induced ethylene production and responses in Arabidopsis thaliana rely on ACS2 and ACS6 gene expression. BMC Plant Biol. 14, 214, 2014.

78. TRINH N.N, HUANG T.L, CHI W.C, FU S.F, CHEN C.C, HUANG H.J. Chromium stress response effect on signal transduction and expression of signaling genes in rice. $\mathrm{J}$ Physiol Plant. 150 (2), 205, 2014.

79. STEFFENS B. The role of ethylene and ROS in salinity, heavy metal, and flooding responses in rice. Front Plant Sci. 5, 685, 2014

80. CAO S., CHEN Z., LIU G., JIANG L., YUAN H., REN G., BIAN X., JIAN H., MA X. The Arabidopsis EthyleneInsensitive 2 gene is required for lead resistance. Plant Physiol Biochem. 47 (4), 308, 2009.

81. ABOZEID A., YING Z., LIN Y., LIU J., ZHANG Z., TANG Z. Ethylene improves root system development under cadmium stress by modulating superoxide anion concentration in Arabidopsis thaliana. Front Plant Sci. 8, 253, 2017.

82. MASOOD A., IQBAL N., KHAN N.A. Role of ethylene in alleviation of cadmium-induced photosynthetic capacity inhibition by sulphur in mustard. Plant Cell Environ. 35, 524, 2012.

83. IAKIMOVA E., KAPCHINA-TOTEVAV., JONG A.J., ATANASSOV A., WOLTERING E. Involvement of ethylene, oxidative stress and lipid-derived signals in cadmium-induced programmed cell death in tomato suspension cells. BMC Plant Biology 5 (Suppl 1), S19, 2005.

84. NANDWAL A.S., KUKREJA S., KUMAR N., SHARMA P.K., JAIN M., MANN A., SINGH S. Plant water status, ethylene evolution, N(2)-fixing efficiency, antioxidant activity and lipid peroxidation in Cicer arietinum L. nodules as affected by short-term salinization and desalinization. J Plant Physiol. 164 (9), 1161, 2007.

85. LIU K., SHEN L., SHENG J. Improvement in cadmium tolerance of tomato seedlings with an antisense DNA for 1-aminocyclopropane-1-carboxylate synthase J. Plant Nutr. 31, 809, 2008.

86. HOSSAIN M.A., BHATTACHARJEE S., ARMIN S.M., QIAN P., XIN W., LI HY., BURRITT D.J., FUJITA M., TRAN L.S. Hydrogen peroxide priming modulates abiotic oxidative stress tolerance: insights from ROS detoxification and scavenging. Front Plant Sci. 16, 6, 420, 2015.

87. MÜLLER M., MUNNÉ-BOSCH S. Ethylene Response Factors: A Key Regulatory Hub in Hormone and Stress Signaling. Plant Physiol. 169 (1), 32, 2015.

88. CAROLINA S., HERNÁNDEZ C., PINO M.T. Plant water stress: Associations between ethylene and abscisic acid response. Chilean J. Agric. Res. 75, supl.1 Chillán ago, 2015.

89. ZHAO X.C., SCHALLER G.E. Effect of salt and osmotic stress upon expression of the ethylene receptor ETR1 in Arabidopsis thaliana. FEBS Lett. 562, 189, 2004.

90. WANG Y., WANG T., LI K., LI X. Genetic analysis of involvement of ETR1 in plant response to salt and osmotic stress, Plant Growth Regul, 54, 261, 2008.

91. MONTEIRO C.C., CARVALHO R.F., GRATÃO P.L., CARVALHO G., TEZOTTO T., MEDICI L.O., PERES L.E.P., AZEVEDO R.A. Biochemical responses of the ethylene-insensitive Never ripe tomato mutant subjected to cadmium and sodium stresses. Environ. Exp. Bot. 71, 306, 2011.

92. FINKELSTEIN R. Abscisic Acid synthesis and response. Arabidopsis Book. 1,11, e0166, 2013.

93. ROYCHOUDHURY A., PAUL S., BASU S. Cross-talk between abscisic acid-dependent and abscisic acidindependent pathways during abiotic stress. Plant Cell Rep. 32, 985, 2013.

94. WANG Y, WANG Y, KAI W, ZHAO B, CHEN P, SUN L, JI K, LI Q, DAI S, SUN Y, WANG Y, PEI Y, LENG P. Transcriptional regulation of abscisic acid signal core components during cucumber seed germination and under $\mathrm{Cu}^{2-}, \mathrm{Zn}^{2-}, \mathrm{NaCl}$ and simulated acid rain stresses. Pplant Physiol Biochem. 76, 67, 2014.

95. LIU X., HOU X. Antagonistic Regulation of ABA and GA in Metabolism and Signaling Pathways. Front Plant Sci. 9, 251,2018

96. ROYCHOUDHURY A., BASU S. Ascorbate-glutathione and plant tolerance to various abiotic stresses, in Oxidative Stress in Plants Causes, Consequences and Tolerance, eds N. A. Anjum, S. Umar, and A. Ahmad (New Delhi: IK International Publishing House Pvt. Ltd), 177, 2012.

97. LIU Z., YAN J.P., LI D.K., LUO Q., YAN Q., LIU Z.B., YE L.M., WANG J.M., LI X.F., YANG Y. UDPglucosyltransferase71c5, a major glucosyltransferase, mediates abscisic acid homeostasis in Arabidopsis. Plant Physiol. 167, 1659, 2015.

98. DONG T., XU Z.Y., PARK Y., KIM D.H., LEE Y., HWANG I. Abscisic acid uridine diphosphate glucosyltransferases play a crucial role in abscisic acid homeostasis in Arabidopsis. Plant Physiol 165, 277, 2014.

99. VERSLUES P.E., ZHU J.K. New developments in abscisic acid perception and metabolism. Curr Opin Plant Biol. 10, 447, 2007. 
100. KUROMORI T., MIYAJI T., YABUUCHI H., SHIMIZU H., SUGIMOTO E., KAMIYA A., MORIYAMA Y., SHINOZAKI K. ABC transporter AtABCG25 is involved in abscisic acid transport and responses. Proc Natl Acad Sci USA. 107, 2361, 2010.

101. BAUER H., ACHE P., LAUTNER S., FROMM J., HARTUNG W., AL-RASHEID K.A., SONNEWALD S., SONNEWALD U., KNEITZ S., LACHMANN N., MENDEL R.R., BITTNER F., HETHERINGTON A.M., HEDRICH R. The stomatal response to reduced relative humidity requires guard cell-autonomous ABA synthesis. Curr Biol. 23, 53, 2013.

102. GUAJARDO E., CORREA J.A., CONTRERASPORCIA L. Role of abscisic acid (ABA) in activating antioxidant tolerance responses to desiccation stress in intertidal seaweed species. Planta. 243 (3), 767, 2016.

103. KIM Y.H., KHAN A.L., KIM D.H., LEE S.Y., KIM K.M., WAQAS M., JUNG H.Y., SHIN J.H., KIM J.G., LEE I.J. Silicon mitigates heavy metal stress by regulating P-type heavy metal ATPases, Oryza sativa low silicon genes, and endogenous phytohormones. BMC Plant Biol. 14, 13, 2014.

104. XIONG L., LEE H., ISHITANI M., ZHU J.K. Regulation of osmotic stress responsive gene expression by the LOS6/ABA1 locus in Arabidopsis. J. Biol. Chem. 277, 8588, 2002.

105. SONG C., YAN Y., ROSADO A., ZHANG Z., CASTELLARIN S.D. ABA Alleviates Uptake and Accumulation of Zinc in Grapevine (Vitis vinifera L.) by Inducing Expression of ZIP and Detoxification-Related Genes. Front. Plant Sci. 10, 872, 2019.

106. FAN S.K., FANG X.Z., GUAN M.Y., YE Y.Q., LIN X.Y., DU S.T., JIN C.W. Exogenous abscisic acid application decreases cadmium accumulation in Arabidopsis plants, which is associated with the inhibition of IRT1mediated cadmium uptake. Front Plant Sci. 16 (5), 721, 2014.

107. SHI W.G., LI H., LIU T.X., POLLE A., PENG C.H., LUO Z.B. Exogenous abscisic acid alleviates zinc uptake and accumulation in Populus $\times$ canescens exposed to excess zinc. Plant Cell Environ. 38 (1), 207, 2015.

108. AGGARWAL A., SHARMA I., TRIPATHI B.N., MUNJAL A.K., BAUNTHIAL M., SHARMA V. Metal Toxicity and Photosynthesis": In book: Photosynthesis: Overviews on Recent Progress \& Future Perspective, 16, IK International Publishing House, New Delhi. 229, 2011.

109. GAO Y., MIAO C., XIA J., MAO L., WANG Y., ZHOU P. plant diversity reduce the effect of multiple heavy metal pollution on soil enzyme activities and microbial community structure. Front Environ Sci Eng. 2, 213, 2012.

110. MUKHOPADHYAY M., MONDAL T.K. Effect of ainc and boron on growth and water relations of Camellia sinensis (L.) O. Kuntze cv. T-78. Natl Acad Sci Lett. 38, 283, 2015.
111. PANTIN F., MONNET F., JANNAUD D., COSTA J.M., RENAUD J., MULLER B., SIMONNEAU T., GENTY B. The dual effect of abscisic acid on stomata. New Phytol. 197 (1), 65, 2013.

112. SARADADEVI R., PALTA J.A., SIDDIQUE K.H.M. ABA-Mediated Stomatal Response in Regulating Water Use during the Development of Terminal Drought in Wheat. Front Plant Sci. 18 (8), 1251, 2017.

113. POMPEU G.B., VILHENA M.B., GRATÃO P.L., CARVALHO R.F., ROSSI M.L., MARTINELLI A.P., AZEVEDO R.A. Abscisic acid-deficient sit tomato mutant responses to cadmium-induced stress. Protoplasma, 254, 771, 2017.

114. WANG J., LIN L., LUO L., LIAO M., LV X., WANG Z., LIANG D., XIA H., WANG X., LAI Y., TANG Y. The effects of abscisic acid (ABA) addition on cadmium accumulation of two ecotypes of Solanum photeinocarpum. Environ Monit Assess. 188, 182, 2016.

115. NOMURA T., ITOUGA M., KOJIMA M., KATO Y., SAKAKIBARA H., HASEZAWA S. Copper mediates auxin signalling to control cell differentiation in the copper moss Scopelophila cataractae. J Exp Bot. 66, 1205, 2015.

116. FÄSSLER E., EVANGELOU M.W., ROBINSON B.H., SCHULIN R. Effects of indole-3-acetic acid (IAA) on sunflower growth and heavy metal uptake in combination with ethylene diamine disuccinic acid (EDDS). Chemosphere. 80, 901, 2010.

117. BASHRI G., PRASAD S.M. Exogenous IAA differentially affects growth, oxidative stress and antioxidants system in $\mathrm{Cd}$ stressed Trigonella foenumgraecum L. seedlings: Toxicity alleviation by upregulation of ascorbate-glutathione cycle. Ecotoxicol Environ Saf. 132, 329, 2016.

118. AGAMI R.A. Pre-soaking in indole-3-acetic acid or spermidine enhances copper tolerance in wheat seedlings. S. Afr. J. Bot. 104, 167, 2016.

119. WANG H., DAI B., SHU X., WANG H., NING P. Effect of Kinetin on Physiological and Biochemical Properties of Maize Seedlings under Arsenic Stress. Adv. Mater. Sci. Eng. 7, 714646, 2015.

120. ESER A., AYDEMIR T. The effect of kinetin on wheat seedlings exposed to boron. Plant Physiol Biochem, 108, 158, 2016.

121. GANGWAR S., SINGH V.P., GARG S.K., PRASAD S.M., MAURYA J.N. Kinetin Supplementation Modifies Chromium (VI) Induced Alterations in Growth and Ammonium Assimilation in Pea Seedlings. Biol Trace Elem Res, 144, 1327, 2011.

122. RUBIO-WILHELMI M.M., SANCHEZ-RODRIGUEZ E., ROSALES M.A., BEGOÑA B., RIOS H.J., ROMERO L., BLUMWALD E., RUIZA J.M. Effect of cytokinins on oxidative stress in tobacco plants under nitrogen deficiency. Environ Exper Bot. 72, 167, 2011.

123. ZHANG B., SHANG S., JABEEN Z., ZHANG G. Involvement of ethylene in alleviation of Cd toxicity by $\mathrm{NaCl}$ in tobacco plants. Ecotoxicol Environ Saf. 101, 64, 2014. 
